\title{
Sex work and online platforms: what should regulation do?
}

\author{
Nick Cowen, School of Social and Political Sciences, University of Lincoln \\ Rachela Colosi, School of Social and Political Sciences, University of Lincoln
}

\begin{abstract}
Purpose

Assess the impact of online platforms on the sex industry, focussing specifically on direct sex work, and evaluate what approaches to platform regulation is likely to align with the interests of sex workers.
\end{abstract}

\section{Design/methodology/approach}

A review of interdisciplinary conceptual and empirical literature on sex work combined with analysis of key issues using a transaction cost framework.

\section{Findings}

Online platforms generally make sex work safer. Regulation aimed at preventing platforms from serving sex workers is likely to harm their welfare.

\section{Research limitations/implications}

Regulation of online platforms should take great care to differentiate coercive sex from consensual sex work, and allow sex workers to experiment with governance mechanisms provided by entrepreneurs.

\section{Originality/value}

The paper demonstrates how a transactions costs approach to market behavior as applied to personal services like ridesharing can also shed light on the challenges that sex workers face, partly as a result of criminalisation, and the dangers of over-regulation.

\section{Introduction}

How should regulators approach the marketing and sale of sexual services on Internet platforms? This is an urgent and controversial question as workers in the sex industry are often among the least advantaged and most at risk of violence or deprivation. It is also a key way that technology entrepreneurs can become entangled with criminal law. One illustration is the U.S. federal government's seizure of the company and website Backpage and conviction of its CEO in 2018 on human trafficking and money-laundering offences (Born, 2019). Concern about Backpage and similar businesses prompted the removal of some platform immunities from liability for content published on Internet platforms under section 230 of the Communications Decency Act. Some scholars have used this example as part of a broader justification for reducing the immunities of third-party platforms in ways that may affect other 
business areas as well freedom of expression on the Internet (Citron and Wittes, 2018).

Sex work is criminalised in most of the United States and is typically prohibited or heavily regulated in other countries in alignment with what we label a 'suppression' approach to policy (Phoenix, 2009; Wakefield and Brents, 2020; Weitzer, 2010). Nevertheless, the direct prosecution of sex workers on moral grounds is not as popular to implement as it once was. As a result, the contemporary rationale for an aggressive stance against platforms that facilitate sex work is that they function as a cover for sexual exploitation and human trafficking (Goldman, 2018; Otravec, 2014). The argument of this paper, by contrast, is that the prurient and stigmatised presentation of sex work in much public debate has led to a blurring of consensual sex work with a distinct problem of non-consensual sexual exploitation (Lerum and Brents, 2016; Chapman-Schmidt, 2019). This mistaken presentation of sex work has encouraged a confusing and ultimately harmful approach to platform regulation. Bringing both the lived experience of sex workers and systematic empirical research into consideration suggests that technology platforms help sex workers engage in self-protection.

Whether defending or critiquing the role of technology platforms in facilitating sex work, scholars have tended to present the issue as a unique problem in need of specific legal solutions (See Sanders et al., 2017). However, considering the sex industry through a transaction cost framework suggest that many of the problems that sex workers face parallels the challenges of workers in legally permitted industries, especially personal services. The main complication is that because sex workers often operate either outside the law or at the periphery of what the law permits, ordinary entrepreneurs are deterred from supporting them while providing opportunity for governance and protection suppliers who are willing to use other illegal means such as violence (Kurtz et al., 2004; Sanders and Campbell, 2007; Vanwesenbeeck, 2017). As a result, decriminalisation would be more likely to improve the welfare of people participating in the sex work.

This paper's position is substantiated by reviewing empirical analyses of sex work from economics, sociology, and public health, and explaining the observed changes in terms of the transactions-costs framework found in new institutional economics. The paper is structured as follows. First, it gives an account of the development of Internet platform regulation and some points of contention surrounding the sex industry. Second, it explains different ways of conceptualising sex work and approaches to sex work regulation. Third, it explains the high transactions costs that sex workers face and the variety of ways that online platforms have helped to reduce them. It concludes by considering how public policy aiming to improve the welfare of sex workers should approach the regulation of online platforms and how this analysis relates to broader analysis of the determinants of labor conditions.

\section{Internet common carriers and their discontents}

Internet commerce and online expression has grown with the support of a relatively permissive legal framework oriented around Section 230 of the Communications Decency Act (CDA) (1996). The CDA was originally intended to prevent indecent and obscene 
material (including written words) from reaching minors. The Supreme Court decision in Reno v. American Civil Liberties Union ${ }^{1}$ (1997) restricted the scope of these provisions to prohibition of obscene materials, including images of child sexual abuse. It excluded indecent materials from direct government regulation on the grounds that their publication was protected by the First Amendment. This prevented the government from explicitly censoring most Internet speech. The provisions of Section 230, however, remained in place. The law treats Internet content providers as common carriers, conduits between parties, and thus responsible for the effective conveyance of information but generally not liable for the content. Protections extend not just to Internet Service Providers but also content providers such as search engines and social media platforms.

Protections for internet service providers and content providers are not absolute. They are required to respond quickly to claims of copyright infringement by removing stolen and republished material. They must act rapidly to remove libellous material. Section 230 of the CDA also permits content providers to block material it judges to be offensive or obscene even if that material is protected by the First Amendment. Thus, Internet content suppliers are permitted to censor communications in a way for which there is not a direct parallel with telephone and mail services.

This has produced a compromise, effective for the facilitation of the growth of Internet services in a way that is suitable for a variety of audiences including families and children (Kosseff, 2019). However, it has its controversies since it relies on delegating powers that the government itself is not permitted to exercise to private-sector common carriers. The government enables internet content providers to censor so long as they act in good faith but has been constrained from setting its own content guidance. Due to the global interconnected nature of the Internet, and the relative ease with which foreign firms can host content using providers based in the United States, this relatively permissive structure set a standard for legal protection for online publication that other regimes were incentivised to imitate, or risk losing commercial relevance. The Internet as we understand it today is arguably uniquely possible because of the First Amendment to the Constitution of the United States.

\section{FOSTA-SESTA and Backpage}

The Internet's functions have grown so that it represents not just a media content provider but also a critical forum for commerce and social expression. The role of platforms as censors of offensive political speech has led to accusations of bias from multiple perspectives. In 2019, President Donald Trump issued an executive order, with difficult to parse legal implications, requiring social media to be politically balanced when censoring content. It has also led to contestation over how far First Amendment provisions can extend to content that facilitates commerce. For example, Amazon.com has made several attempts to use Section 230 to claim immunity from advertising defective or dangerous products marketed by third parties (Doyer, 2020; Citron and Wittes, 2018).

In this context, the criminalisation of online platforms that facilitate sex work has attracted a rare bipartisan consensus. With the indecency route to regulation blocked by the Supreme Court, prosecutors have instead aggressively pursued firms who can be shown to benefit economically from sex work (Goldman, 2018). Although normally couched in terms of

\footnotetext{
${ }^{1} 521$ U.S. 844
} 
protecting sex workers, and especially stopping human trafficking, in practice the facilitation of any sex work attracts the attention of state and federal police and prosecutors (Weitzer, 2007, 2015). The popularity of this approach, and the tying of online advertising of sex work to immigration violations, prompted the passing into law in 2018 of FOSTA-SESTA. This explicitly extended liability for criminal prosecution to online platforms by removing their safe harbor immunities as common carriers. This was based on two bi-partisan bills, one initiated in the U.S. Senate (Stop Enabling Sex Traffickers Act), the other in the House of Representatives (Allow States and Victims to Fight Online Sex Trafficking Act).

The prosecution of Backpage illustrates the aggressive approach to online sex work regulation. Backpage was a classified listings site and the world's most prominent platform for sex workers arranging meetings with clients until it was seized in April 2018 by the United States Department of Justice (Goldman, 2018). The launch of Backpage was prompted by the success of an older firm, Craigslist founded in 1994 as a classified emailing list that rapidly expanded into a website. Craigslist is a general classified listing website with popular sections on jobs, housing, used cars, second-hand items and events. It had a personals sections that at one point was a key point of contact for lesbian and gay meetings in regions without settled and public LGBTQ communities (Rostow, 2005). Alongside this, it permitted 'erotic services' listings until this was shut down after pressure from several state attorneys general (Reynolds, 2020). After FOSTA-SESTA was made law, Craigslist removed the personals section altogether in order to avoid any accusation of facilitating sex work even if they were explicitly advertised as mutual, non-commercial liaisons.

Unlike Craigslist, Backpage took a different approach and relied on Section 230 to defend its business practices. This is how it became a dominant platform for sex work advertising listings on the Internet. A commercial research group estimate that at one point $70 \%$ of online revenue for erotic listings went to Backpage (Whittaker, 2012). Backpage and its business model were challenged in a series of lawsuits regarding advertisements from coerced sex workers, including minors. Despite winning several court cases, Backpage's offices in Texas were eventually raided. CEO Carl Ferrer, as well as several other company employees, were arrested. The Electronic Frontier Foundation argued that at least some of the charges breached First Amendment protections (Cope, 2017). The charges and investigation devastated the platform. Ferrer pled guilty to facilitating prostitution and money laundering. Backpage, as a company, pled guilty to human trafficking.

The nature of plea bargaining in the United States criminal justice system means that it is difficult to infer with confidence the guilt of these parties (Barkow, 2019; Surprenant and Brennan, 2020). Moreover, the shutdown of Backpage was felt as a substantial cost for sex workers who lost an important forum where they were able to control the conduct of their business (Witt, 2018; Tichenor, 2020; Q, 2018). This raises a set of controversial questions. Is criminalisation an appropriate response to platforms that facilitate sex work? What costs and benefits for sex workers and their customers are associated with the use of online platforms? What kind and extent of regulation do the social costs of sex work justify? As is now shown, much of this controversy lies in the different ways that activists and policymakers conceptualise and evaluate sex work.

\section{Conceptualising online sex work}

To provide some context for the article, it is necessary to explore the concept of sex work, and to situate it within online spaces. Although a very basic interest for a great many people, sex is remarkably hard to define in its totality. Posner (1998) controversially suggests that for most people, the act of sexual intercourse is typically preferred and that the variegated 
alternatives function as substitutes that are associated with lower risks or costs to provide or procure. The proliferation of diverse sexual practices and orientations as the freedom to express sexual interests has grown suggests this is a substantial simplification. Instead, the sexual preferences that drive people are remarkably diverse. This means that sex work, sexual services or products provided in return for renumeration, represents a similarly vast array of practices that are often highly abstracted from acts of intercourse between people, and may not involve any physical stimulation at all. For this reason, scholars often distinguish between 'direct' sex work, which involves intimate bodily interaction aimed at sexual relief, and 'indirect' sex work that includes a wide array of services such as erotic dancing, fetish performances, pornography production, phone and text-based sex chat and, increasingly, liveInternet performances (Sanders et al., 2018, 2017).

Traditionally, sex work is often depicted as gendered, with women portrayed as the service providers and men as the consumers (Davidson, 2002; Jeffreys, 2009). However, more recently, scholars have challenged this, suggesting that it essentialises sex work, and oversimplifies the sex industry, which inevitably influences policy decisions in the regulation of sex work (Kingston and Smith, 2020). People who engage with sexual services, including those who provide the service and consume it, are diverse and include members from LGBTQ+ communities, as well as Cisgendered men and women (Logan, 2010; Smith and Attwood, 2013; Smith et al., 2015). With such a diverse profile, political decisions regarding the regulation of sex work should consider the different experiences and needs of those engaging with sex markets (Kingston and Smith, 2020).

The practice of sex work continues to move online, with scholars contending that most sexual services involve some level of online interaction (McLean, 2015; Pitcher, 2015; Sanders et al., 2016, 2017); potentially increased by the recent lockdown conditions imposed in response to the Covid-19 epidemic. Moreover, the advertising of sexual services and practices of sex workers are predominantly web-based, which is clearly evidenced in the reduction of face-toface services (Sanders et al., 2016, 2017; Brooks-Gordon et al., 2015). Despite this, policy continues to focus on regulating face-to-face sex work, largely ignoring the advancement of online sexual services and advertising (Sanders et al., 2017); this to some extent is indicative of misinformation about sex markets (Kingston and Smith, 2020), but equally reflects some of the challenges of regulating online spaces (McKee et al., 2015). Where the regulation of online platforms has been attempted, as discussed later in this article, adult content has often been censored, and in some cases prohibited, by internet service providers and by site conveners. A notable example, of restricting adult content can be identified in the changes imposed by the owners of Tumblr prohibiting any sexual content. This disrupted several communities (including sex work workers) who used this site to express and advertise their sexuality (Colosi and Lister, 2019).

\section{Different models of sex work regulation}

While scholars agree that the sex industry has expanded significantly (even become 'mainstream') (Brents and Sanders, 2010; Jeffreys, 2009), there is substantial disagreement over the normative implications of sex work and whether policy should aim to ensure safety and consent or actively supressed (Phoenix, 2009). McKenzie and Tullock (1975) explain sex work in terms of the different demand and supply schedules between individuals and, on average, between men and women (cf. Baumeister and Vohs, 2004). Although McKenzie and 
Tullock do not take a normative standpoint, the implication is that the emergence of sex work can be explained out of mutual interest rather than coercion. Accounts from some current and former sex workers suggest this is indeed often the case (Magnanti, 2013). A classical liberal approach to the social morality of commerce posits that anything that informed, consenting adults are permitted to do for free are also presumptively permitted to sell (Brennan and Jaworski, 2016). According to this liberal view, the freedom to participate in sex work follows from a commitment to sexual and economic autonomy.

There are many critical perspectives on liberalism. Within the debate over sex work, the most prominent is radical feminism. Radical feminism proposes that patriarchy, male domination of women, is a pervasive feature of modern societies, including all that are premised on a supposed liberal capitalism (Pateman, 1989). Men's 'liberal' socio-economic freedom requires the subordination of women. In this context, the notion that women can consent to (heterosexual) sex is questioned, if not outright rejected (See Chapkis, 1997). Refusals to participate in sex are silenced; women's consent to sex is either presumed or ignored as sex from women is considered a right (Langton, 2009). Although several radical feminists are critical of all forms of heterosexual activity that take place within existing societies (See Dworkin, 1987; Kitzinger, 1992), sex work, or prostitution as is the preferred label (Barry, 1995; Jeffreys, 2009), is all the more insidious because it relies on both actual violence in the industry and the subtle coercion of poverty and social marginalisation.

The highly divergent evaluations of the nature of sex work in commercial societies translates into similarly varied approaches to regulating sex work, that can be divided into suppressive or permissive models. The different models are rarely exclusively implemented and frequently vary by local jurisdiction. A public policy framework may prohibit certain types of sex work while licensing or simply ignoring other kinds.

\section{Suppression models}

Although explicitly prohibitionist policy is not so prominent in contemporary policy discussion, it was highly influential in establishing many legal frameworks that have persisted into the $21^{\text {st }}$ century. In most parts of the United States, sex work is criminalised under various state laws (Wakefield and Brents, 2020). In the United Kingdom, sex work itself is legal but many practices used to facilitate it, including public solicitation and establishing a shared workplace (or brothel) is criminalised (Sanders et al., 2018).

Sex work has often been treated as a form of vagrancy or part of generic anti-social activity in traditional legal systems. More systematic attempts at suppression through legal codification of sex work emerged in the late $19^{\text {th }}$ and $20^{\text {th }}$ centuries. Initially, laws regulating sex work tended to be premised on the containment of contagious diseases (Sanders et al., 2018). But the justifications for prohibition soon took on a more explicitly moralised form (Weitzer, 2009). In the United States, the Progressive movement spearheaded this approach to reform. Progressives endorse what has subsequently been identified as a Wilsonian view of government as a powerful agent that should be harnessed to achieve a broad conception of the good (Ostrom, 2008), as well as an expansive notion of the police power of the states to make law to improve the health, safety, morals, and general welfare of the people.

There were several ideological sources of the Progressive movement. A revived Christian religious fervour, in reaction to modernity, played an important role especially in policies 
aimed at temperance which were hostile to alcohol consumption and sexual license. A moral panic surrounding 'white slavery', driven by exaggerated stories of traffic in women across state borders, inspired the Mann Act of 1910, which blurred the distinction between consensual and non-consensual sexual activity (Russo, 2020, p.322). However, there were also justifications that drew on scientific discourses, such as eugenics. Some policymakers were concerned with maintaining the integrity of the family and ensuring women remained chaste for marriage in order to maintain racial purity (Kevles, 1999).

Although, in many respects, hostile to individual women's freedom, the movement was also aligned with expanding women's suffrage and some women played a significant public role driving Progressive issues. Political voice was heavily weighted to women who were perceived to play a respectable role in society and the family. Reasons for the underlying popular support of the Progressive movement are complex and contested. One source was a public perception of existing governments as both incompetent and corrupt, a complaint that became conceptually linked with personal vice (McCormick, 1981; Hays, 1964).

As was the case more infamously for alcohol prohibition, Progressive reformers overestimated the power that government had to improve people's morality (as they saw it) and underestimated the unintended consequences of criminalising a profitable commercial sector. Prohibitions of any trade create opportunities for rent seeking for the privilege of supplying it (Paul and Wilhite, 1994). Absent formal legal recognition of the rights and property necessary to engage in trade, that competition will be settled with the threat and use of violence. Hence, criminalisation did not eliminate sex work but rather led to its consolidation under the control of organised crime (Simowitz, 2013). This contributes to the association that sex work has with violence and abuse.

Contemporary approaches to sex work suppression tend to use the label abolition rather than prohibition. The label 'abolition' keeps the deliberate allusion to the slavery abolitionist movement of the $19^{\text {th }}$ century. As with prohibition in the $19^{\text {th }}$ and early $20^{\text {th }}$ century, religious groups are prominent supporters of an abolitionist model. In addition, secular radical feminists, who critique patriarchy and heterosexism in other aspects of society, frequently support the abolitionist model (Weitzer, 2009, p.20; Phoenix, 2009). Rather than conceptualising sex workers as fallen women who bring moral degradation and disorder to a community, while also being a vector for communicative diseases, this model presents sex workers primarily as victims forced through both circumstances and criminal exploiters into the sector (See, for example, Farley, 2004; Jeffreys, 2009; Raymond, 2013). Rather than deserving criminalisation, sex workers need help exiting the industry and formulating new work and life identities. Moreover, proponents of sex work suppression argue that legal sex work encourages violence against women and lowers the status of women in society more generally (Weitzer, 2009).

A concrete example of this approach to policy is what has become known as the Nordic or Swedish model whereby buyers of sex are criminalised while sex workers themselves are encouraged to engage with social services (Vuolajärvi, 2019; McMenzie et al., 2019). The aim of this approach is to 'end demand' as it is argued that it is the preferences of men to use sexual services that drive the development of the sector. A practical issue with the Nordic model is that it renders all clients of sex workers offenders, and makes sex workers willing victims to a crime. It criminalises the exchange by targeting one of the parties engaged in it. 
This inevitably creates an antagonistic relationship between sex workers and police because the authorities are attempting to disrupt the transaction. This means that sex workers often need to hide their activities from authorities. They may struggle to integrate their work with access to mainstream public and financial services (Lister, 2018). Sex workers cannot take steps to establish more durable arrangements that may better ensure their safety. Bernstein (2012) argues that one important contributor to contemporary abolitionist discourse is what she identifies as carceral feminism: this is the use punitive criminal justice policies in an attempt to achieve feminist policy goals such as gender equality.

A conceptual challenge for abolitionists is that, unlike the institutions of slavery, many individuals participating in sex work (or who have participated in sex work) deny that they have been forced. Some describe sex work as a positive feature of their lives, while many describe it pragmatically as the best form of paid work available to them in what may be a range of limited options (Abel, 2014; Mac and Smith, 2018). Historical slavery abolitionists contended with defenders of slavery, those who justified and naturalised the practice, but generally not with people who contested where slavery existed. This suggests that the abolitionist model does not capture the range of understandings of the practice of sex work.

A plausible argument in favour of the suppression model is that legal sex work between consenting adults expands the sex industry and encourages coercive trafficking while making it more difficult for police to detect it (Farley, 2004; Raymond, 2013). Some evidence, focused on comparing different approaches to sex work regulation in Europe, supports this position (Jakobsson and Kotsadam, 2013). Potential weaknesses with this argument is that the definition of human trafficking itself is driven by policymakers and law enforcement rather than individuals involved in sex work (Agustín, 2006, 2002). When discovered committing immigration violations, individuals might be placed under pressure to identify officially as trafficking victims to avoid criminal penalties (Chapkis, 2003).

Suppression approaches are remarkably prevalent globally (Armstrong, 2020). Considered through this lens, criminalisation of technology platforms that facilitate sex work follows logically. If it is impossible for people to be a sex worker consensually, then it follows that the client and any involved third-party is responsible for serious crime. Classically, third parties are presented as violent pimps. Third-party platforms that permit the advertising of sex work must really be facilitating the practices of pimps, allowing them to sell access to the people they control more effectively. On this account, permitting more exploitation cannot be to the advantage of those who are exploited.

\section{Permissive models}

There are more permissive approaches to sex work which are occasionally implemented or at least influence policy reforms. These tend to be premised on the notion that sex workers have capacity for rational agency and so engage in trade because they feel it benefits them when compared to other possible courses of action. Criminalisation restricts their available legal options and so risks putting them in a worse position than they otherwise would be.

Criminalisation also increases stigma associated with sex work even if it only directly targets clients (Bettio et al., 2017). Permissive models recognise that there are severe personal risks, as well as social costs, associated with the sex industry. The purpose of law and regulation on this account is to allow people to pursue their own ends as they see them while preventing harm to others. This means protecting individuals from violence, theft or deception in the 
process of participation in sex work, and the prevention of communicable diseases. The modern impetus for harm reduction approaches was driven by the AIDS epidemic where the social costs of failure to provide sex workers with access to public health services were particularly salient (Rekart, 2005; Cusick, 2006).

Although each policy has unique characteristics, two labels help to differentiate possible models. The first is legalisation. This model acknowledges the welfare value of providing safe spaces to conduct sex work but proposes that the various nuisances and risks associated with the industry require special regulation. This is often through requiring sex workers to register and undertake regular health checks as well as restriction of business to licensed venues in limited locations that can be easily inspected by public officials. The intention is often to keep visible signs of the sex industry away from residential areas and areas used by families. Versions of this model can be found in Germany and the Netherlands. It is also present in a few counties of Nevada, which license some brothels but not other forms of direct sex work (Wakefield and Brents, 2020).

The disadvantages of a legalisation model parallel those found in other licensing and regulation frameworks. There is a trade-off between increased safety and security and costs of compliance. If the costs of compliance are too high, then some sex workers may decide to opt out of the legal framework. In addition, legislative models often discriminate between settled citizens and migrants. Legalisation may be introduced to achieve other policy goals than the welfare of sex workers and clients, such as immigration control and making sex work less visible to the public (Hubbard et al., 2008). Supposed legalisation policies can act as a cover for suppression (Scoular, 2010).

The second label is decriminalisation. This model is premised on the idea that sex work is close enough to other forms of work and exchange such that the policy does not require compulsory licensing (Mac and Smith, 2018). On this account. the external costs of the sex industry are insufficient to justify regulation beyond standard legal remedies found in civil society. The closest example to an implemented version of decriminalisation is in New Zealand where sex workers are encouraged to use licensed brothels but there are no penalties for operating independently (Armstrong and Abel, 2020). For both legalisation and decriminalisation models, the intention is not to eliminate sex work but rather to shift individuals working within the sex industry away from coercive, high-risk practices and towards healthier, safer, more secure and more socially integrated practices.

Identifying the performance of different legal frameworks is a challenging task. Relevant data is harder to collect than for many ordinary markets, especially in the case of direct sex work since most transactions are unrecorded and conducted privately. Observations of crimes like violence against women and human trafficking often reflect enforcement priorities and so comparisons between different legal regimes are contestable. Nevertheless, some recent empirical research suggests there are generally welfare benefits to permissive models. When directly compared, consensual sex work is more profitable and easier to manage than coerced sex work (Marcus et al., 2016). This suggests, in principle, that a sufficiently permissive regime that respects the rights and welfare of sex workers and their clients are likely to be more efficient than coercive alternatives. They could replace more coercive forms of adult sex work. Moreover, Cunningham and Shah (2018) provide some evidence from the U.S that points in favour specifically of the decriminalisation of adult sex work. They exploited the plausibly exogenous decriminalisation of indoor sex work in Rhode Island, imposed unexpectedly by a District Court judge. They found that decriminalisation allowed sex 
workers to adopt safer working practices associated with a substantial reduction in rape victimisation and prevalence of sexually transmitted infections. Converse evidence, exploring a recent, initially unexpected, criminalisation of sex work in one district in East Java, Indonesia, found that criminalisation was associated with increased sexually-transmitted infections and lower incomes for former sex workers, impeding their capacity to support their families (Cameron et al., 2020). The next section introduces the transaction costs framework, explains how online platforms reduce transaction costs and applies this framework to sex work.

\section{Technology platforms and transaction costs}

How can the role of technology platforms in changing the sex industry best be understood? The range of impacts and changes in the sector can be explained effectively by thinking through the harms that sex workers face as transaction costs. The concept of transaction costs is central to the contemporary study of economic organization. A basic premise of new institutional economics is that a great deal of variation between successful enterprises, and indeed successful economies, is explained by the extent to which organizations, institutions and social norms reduce transaction costs (North, 1990; Williamson, 1985; Coase, 1937). Transaction costs are the burdens associated with engaging in exchange. If the burdens are too high, exchanges that are, in principle, mutually beneficial will not take place, vitiating potential welfare gains and productivity improvements that would otherwise be achieved through specialization and coordination.

The transaction costs framework has been fruitfully applied to the development of online platforms, especially the emergence of the sharing economy (Munger, 2018; Rochet and Tirole, 2006; Oranburg and Palagashvili, 2020). Lobel (2018) offers a useful typology of transaction costs that platforms can help at various stages of an exchange: 1) search costs 2) bargaining costs, and 3) policing and enforcing costs. Search costs refers to the time, resources and effort required for two parties interested in trading to find each other. Bargaining costs refer to the time and resources it takes to settle on a price that is mutually agreeable and beneficial to both parties. Policing and enforcement costs refers to costs of securing one's person and property, as well as ensuring that other parties supply their side of the agreement without violence or nuisance.

Platforms such as Uber and Lyft offer paradigmatic examples of how platforms can reduce these types of transaction costs. Their smartphone apps that link to their platforms reduce search, bargaining and policing costs by using the GPS locations of drivers and riders to match much more efficiently than hailing for a ride on the street, estimate the full cost of the journey in advance and prior registration to identify bad actors. This result is more driving hours are spent with a passenger than with a taxicab system (Cramer and Krueger, 2016) and an observable increase in consumer surplus (Cohen et al., 2016). The impact of ridesharing on crime, road fatalities and other social costs is currently controversial with some studies identifying indirect benefits, others costs (Barrios et al., 2020; Dills and Mulholland, 2018; Morrison et al., 2018). There may be scope for self-regulation or municipal regulation to reduce these social costs (Cohen and Sundararajan, 2015). On the other hand, the welfare benefits of the greater convenience and lower costs associated with such platforms should not be overlooked. As is now shown, this explanation for the emergence and value of platforms as applied to sharing platforms is a helpful lens through which to consider sex work.

Applying the transaction costs framework to sex work 
A rich empirical literature identifies many of the risks and harms that sex workers face that can be considered within a transactions cost framework (Connelly et al., 2018). Because of the extra-legal nature of much sex work, the associated transaction costs can be much higher than in other sectors. For example, Sanders and Campbell (2007) draw on accounts of indoor sex workers to establish what sort of risks they face. They found that key risks associated with their workplace were robbery, non-negotiated acts, removal of condoms, rude and disruptive behaviour and underpayment. The risks are high, but this also means that online platforms do not have to be even as sophisticated as a service such as Uber while still substantially reducing costs compared to relevant alternatives.

There are several ways in which platforms can reduce transaction costs associated with sex work (Sanders et al., 2020). They can lower the transaction costs associated with an existing approach to sex work; they can lower the costs for indirect sex work, thus allowing sex workers to switch into safer parts of the sector; and they create new forms of indirect sex work with lower transaction costs to traditional forms. The facilitation of direct sex work is the most controversial and prompted the passing of FOSTA-SESTA so is an appropriate element on which to focus. Online platforms help reduce all three kinds of transaction costs associated with direct sex work (Sanders et al., 2017). Public marketing of sex work is usually discouraged or outright prohibited. This means that sex workers must rely on ephemeral forms of advertising. This includes waiting or walking on public streets where sex workers and clients are known to meet, or using discreet ads left in public places such as phone booths. Alternatively, they may rely on paid third parties ('pimps' or 'madams') to attract and assess clients (Horning and Marcus, 2018; Marcus et al., 2019). Online platforms provide a virtual focal point where sex workers can advertise, and potential clients can search for available opportunities. This substantially reduces the search costs of the two parties. This allows sex workers to build less ephemeral and more accessible professional profiles allowing them eventually to set higher prices for specialised services or become more selective about their clients (Jones, 2015, p.562).

Bargaining often presents a point of vulnerability for sex worker and client. Conducted on the street, both may have little time to agree the exchange, and for the sex worker to assess the true intent of the client and their ability to pay, without attracting unwanted attention by police or other members of the public. By contrast, an online platform allows indicative prices for services to be advertised in advance and for bargaining to take place in a more relaxed and less dangerous context through discreet private messaging. Prominent examples of platforms that facilitate this improved search and bargaining for direct sex work have included Craigslist, Backpage, RedBook and The Erotic Review before they were shutdown (Steuer, 2015). They give sex workers an opportunity to exchange information with clients through private, safer messaging services, thus allowing them to become familiar with each other before having to commit to an in-person meeting.

Policing and enforcement are chronic challenges for direct sex work because formal legal regimes generally do not enforce agreements between sex workers and clients. Moreover, since both parties are engaging in what both public and police generally see as illicit activity, they are less likely to report being the victim of theft, deception or violence (Lister, 2018). In this context, extra-legal mechanisms for establishing trust between parties, especially reputation within a community of known clients and sex workers, are much more important than in licensed or permitted industries. Sex workers take steps within their constrained 
resources and opportunities to improve their security. They may use informal social networks to identify clients who are non-violent and will reliably pay (Sanders et al., 2017). They can share knowledge between trusted associates to identify potentially dangerous clients. Indeed, one non-profit platform based in the United Kingdom, National Ugly Mugs, initially launched by the British Home Office, has harnessed this informal practice among sex workers to encourage information sharing about bad clients (Connelly et al., 2018; Sanders et al., 2016).

When it comes to engaging with individuals not previously known to a sex worker, clients might be required to produce a note or letter of introduction from other sex workers known within the profession or give references that can vouch for their character. Online platforms facilitate these strategies by making it much easier to share information about clients and expand the network of trusted parties. Some platforms encourage sex workers to exchange information with each other, thus spreading information about bad or dangerous clients much more effectively over large distances. One platform, Preferred411, specializes in connecting people with verified identities (Rigg, 2010; Zukerman, 2011). Other platforms encourage clients of sex workers to interact with each other and share information in online forms. An important feature of these interactions is an education of novice clients in proper conduct with regards to contacting sex workers and risk-reduction methods, especially in areas where sex work is illegal (Horswill and Weitzer, 2018). Clients communicate expectations about the process of verification and promote a common moral framework to each other which contributes to safer transactions (Sanders et al., 2020, p.31).

The availability of these platforms has allowed many sex workers to transition from exchanges on the street to indoor areas and to rely less on risky practices (Cunningham and Kendall, 2011). Tentative evidence suggests that the availability of Craigslist, for a time the most known platform for sexual services, substantially reduced the number of female victims of homicide (Cunningham et al., 2019).

\section{The consequences of suppression}

The available evidence suggests that the growth of online platforms has generally been beneficial to the welfare of sex workers. Due to the still recent nature of the shift in policy towards the deliberate suppression of platforms, formal observations of the policy's effects have yet to become available. However, attempts to regulate online platforms to exclude the facilitation of sex work appear to have had negative consequences at least according to research conducted within the sex work community. A survey of sex workers in Rhode Island revealed that the loss of online opportunities for advertising had to led to the re-adoption of more dangerous working practices (Jackson and Heineman, 2018). A survey of street-based sex workers based in Massachusetts reported increases in income instability and a reduction in personal agency as a result of the passing of FOSTA-SESTA (Blunt and Wolf, 2020). In addition to loss of advertising, sex workers fear that the platforms they used for reporting violent clients come under the broad prohibition that FOSTA-SESTA uses. Sex workers in New York have reported being more likely to be targeted by police for 'loitering' because of their greater reliance on street advertisement following the reduction of online advertising opportunity (Witt, 2018).

A broader survey found that a majority of sex workers had recently been subject to threats of violence, exploitation or coercive attempts to obtain free services, some from people attempting to establish themselves as pimps, which some respondents associated directly with the passing of FOSTA-SESTA (Peterson et al., 2019). This aligns with personal accounts of 
sex workers being compelled to return to using pimps that they had previously found to be unnecessary for conducting their business when it became internet-based (Cole, 2018). This is suggestive that FOSTA-SESTA has undermined some of the crowding-out of coercive practices in the sector that platform had facilitated. For some sex workers, the next best option to relying on platforms is not exiting the sex industry, but continuing in the sector while engaging in risky practices that attract the attention of coercive actors. These are 'inelastic' sex workers who have relatively unattractive outside options (cf. Cunningham et al., 2019). Although direct evidence is not yet available, presumably some 'elastic' sex workers were encouraged to exit the sector for less lucrative, but safer, alternatives.

FOSTA-SESTA also compounded pre-existing discrimination against sex workers on mainstream financial technology platforms. Sex workers have to disguise the kind of work they are engaged and are vulnerable to being removed from a platform, often losing earned income in the process. With limited access to mainstream financial platforms, many sex workers have resorted to more specialised platforms with much higher transaction fees (Blunt et al., 2020). Moreover, due to the global reach of Internet platforms, the loss of Backpage and US-based platforms had impacts outside US jurisdictions (Peterson et al., 2019). For example, many sex workers in New Zealand had used Backpage for advertising before it was shutdown. When that option was removed, some sex workers were compelled back into working in brothels. Others attempted to use New Zealand-based online platforms as an alternative but these often had an inadequate number of clients to maintain a secure income (Tichenor, 2020). One alternative platform enforces a restrictive exclusivity requirement on sex workers while Backpage had not.

These reports are consistent with the transaction costs account of platform goods. The prohibition and curtailment of platform services for sex workers has generated costs in terms of reduced income and security for sex workers. In some cases, sex workers have made adjustments that maintain an online presence but often by adopting inferior products.

\section{Policy Implications}

What policy implications can be drawn from the transaction costs approach to understanding the sex work sector and the role of online platforms? Generally, this account suggests that permissive approaches, and especially decriminalisation, are likely to have welfare benefits for both sex workers and clients. Our key observation is that granting rights to engage in sex work generates opportunities for both market participants and entrepreneurs to innovate and contract. This means that, while there are well-documented costs and externalities associated with the sector, these problems are not inevitable but can be progressively ameliorated when the autonomy of participants is respected. Decriminalisation does not imply acceptance of violence and exploitation, merely recognition that effective solutions are likely to come from bottom-up experimentation within the sector and sector self-governance facilitated by platforms.

Our reasoning for this is that much sex work takes place due to the mutual benefit derived by both sex worker and client. By contrast, violent, abusive and exploitative events are cases of disequilibrium outcomes (cf. Shortland, 2019). They are not intended outcomes of faithful participants. Evidence for this can be found in the way that many street sex workers describe passers-by, police and other people who morally object to their presence, rather than clients, as primary sources of violence (Armstrong, 2014, 2019; Sanders et al., 2020, p.34). 
Offenders, of course, may pose as clients in order to access sex workers but with the real intention of attacking or robbing them (Kinnell, 2006). This presents a parallel problem to theft or fraud, or risk of violence, in other market exchanges. Such outcomes can be reduced and avoided by strengthening institutional mechanisms that allow workers to differentiate genuine clients and mutual co-operators from potential threats. Moreover, experienced clients tend to be less likely to be arrested suggesting that, as transactions become regularised, both sides in the exchange are likely to benefit without disturbing the community around them (Monto and Milrod, 2014; Sanders et al., 2020, p.31).

As indicated above, one contributor to the relatively high prevalence of violent victimization of sex workers is the lack of official recognition of sex work as work entitled to ordinary civil legal protections. When police refrain from targeting sex workers or their clients, then information sharing between the sector and authorities have facilitated sex worker protection and successful deterrence of bad actors (Penfold et al., 2004). However, such policy successes are limited when implemented based on the discretion of authorities and without legislative support. Without the recognition of formal rights for sex workers, such as the right to rent or own premises where their activities can be legally conducted, it is possible for cooperation to be undermined by a change in police policy. Sex workers face regime uncertainty when engaging with authorities. This deters them from adopting longer term strategies that might better ensure their security as they may, at little notice, be compelled change their level of visibility or move to a new location.

Malicious activity and fraud occur in all online marketplaces because they are open-access and facilitate exchange among strangers (Garg and Nilizadeh, 2013). Marketplaces can be used to sell dangerous or stolen goods. Online marketplaces for sex work face parallel problems, the most extreme being cases of human trafficking. On the other hand, online platforms aiming at supplying legitimate goods frequently benefit from offering user protections (Tadelis, 2016). For example, eBay and PayPal became popular platforms by offering additional protections to buyers and sellers (Trautman, 2016). This is the function that Craigslist adopted for sex work before state authorities pushed it out of the sector (Cunningham and Kendall, 2016; Cunningham et al., 2019; Otravec, 2014). The main difference is that online platforms serving sex workers moved into a sector where authorities had previously discouraged formal mechanisms to manage risk and exclude malicious actors. The suppression approach to platforms that the U.S. Government has adopted has progressively reduced the number of openly competing platforms in the sector, and, moreover, pushed more well-known brands like Craigslist out first. This has left sex workers with fewer options and likely made it harder for platforms to compete explicitly on safety and trust.

When common carrier protections are in place, cooperation between online platforms and police authorities, as well as NGOs specialising in human trafficking, is easier to establish. For example, Backpage was able to supply evidence used to prosecute bad actors such as human traffickers when it was in operation (Q, 2018). Thus, the common carrier protection regime that Reno vs ACLU helped inaugurate did not only facilitate commerce. By allowing online platforms to inspect and filter content, it permitted some regularisation of previously disorderly markets. Furthermore, decriminalisation of platforms that facilitate sex work would permit competition between platforms. For these reasons, FOSTA-SESTA should be amended to better distinguish the facilitation of consensual sex work and coercive sex work, 
and protect platforms that serve sex workers that act in good faith to prevent sexual exploitation from prosecution. This should be aligned with broader reforms to decriminalise sex work under national and state laws.

\section{Broader parallels with coercion in labor markets}

As we describe above, issues surrounding sex work have often been segregated from mainstream scholarly discussion. This has led to the facilitation of sex work through online platforms being presented as a unique problem that requires its own analysis and legal constraints. What we have shown is that applying a transaction costs framework, familiar from the analysis of economic activity in other sectors, can help de-mystify the specific challenges that sex workers face and the role that intermediaries play in reducing frictions to voluntary mutually beneficial exchanges.

Similarly, explaining the prevalence of coercion in sex work and how to reduce it can be helped by including it within a broader understanding of coercive labor practices. Unfree labor is a substantial feature of the modern economy, observed particularly in the global garment trade (LeBaron and Phillips, 2019). It presents an urgent ethical and legal challenge, albeit one that has achieved less salience politically because the production of clothing is not so easily moralised or sensationalised as sex work. It is a product that everyone needs and so there is no minority consumer group to stigmatise. A general prediction is that the existence of outside options for workers will reduce the effectiveness, and therefore prevalence, of coercive practices (Acemoglu and Wolitzky, 2011). This aligns with the evidence we have presented suggesting that increasing opportunities for sex workers may not necessarily cause them to exit the sector, but does allow them to reduce risks of violence and operate without pimps.

Research into the political economy of unfree labor sometimes follows a Marxist paradigm that explains workplace coercion as determined by the interests of capital, or a neo-classical paradigm that explains workplace coercion as a result of market failure. Both tend to highlight the lack of state regulation and the power of business as the underlying cause. More recent research, however, highlights the significance of political institutions not just for addressing the problem of unfree labour but sometimes facilitating it (LeBaron and Phillips, 2019). Examples of facilitation can include the removal of labor protections and the prevention of legal migration and border enforcement, as well as explicitly state-sanctioned or controlled labor coercion such as in prisons and concentration camps. Seen through this lens, state prohibitions on sex workers working together, forming their own trade associations and utilising protective strategies availed by platforms are examples of governments, intentionally or not, facilitating spaces for coercive labor.

Our account also aligns with assessments of the ethics of poor labor conditions and attempts to reform them in the absence of understanding background conditions or relevant alternatives for workers. For example, Powell (2014) critically explores widely publicised campaigns against sweatshops in global supply chains; he finds that the wages and conditions cited as exploitative are generally superior to typical working conditions in countries where sweatshops are located. Moreover, sweatshops can be instrumental in generating sustained economic growth in undeveloped economies. On our account, it is important to distinguish between poor working conditions that result from coercion and those resulting from choice within the economic and social constraints that workers face. Seldom can a reduction of 
worker choice lead either to superior economic outcomes or improvement in social status (Zwolinski, 2012). Increasing choice, through institutional reform or the distribution of resources to the disadvantaged, is more likely to be successful. Similarly, the selling of sexual services on Internet platforms makes the sector, including examples of poor working conditions within it, more salient and open to public criticism. However, shutting them down and pushing sex work to the periphery will still harm workers.

\section{Conclusion}

What does a humane approach to the regulation of sex work on online platforms look like? Sex work is a controversial issue, one that has come to be associated with fundamental debates about the place of women in society, the problem of gender-based violence and the extent to which commerce should be permitted for the provision of intimacy. This is despite empirical observations that indicate the sector is much more complex and diverse than a simple gendered lens presumes. Empirical research highlights the capacity of many sex workers for personal agency, as well as the variety of people engaged in sex work beyond the classic gender divide. Many sex workers are neither coerced nor behave irrationally (Tullock and McKenzie, 1975). They are often pursuing deliberate ends within the economic and social constraints that they face, including the stigma that society attaches to their choice of occupation (Bettio et al., 2017). To supress sex work outright is a denial of autonomy.

As is the case in other personal services, there is substantial evidence that online platforms serving sex workers have helped to increase their income and welfare by lowering transaction costs and especially decreasing their reliance on risky practices to attract business. For these reasons, many sex workers protested the closure of Backpage and the passing of FOSTASESTA into law which forced many of them to adopt less safe working practices (Q, 2018). There is a distressing lack of sex workers' voices in local and national policy processes, itself a reflection of the continued stigma attached to the occupation. A better approach would allow online platforms that choose to serve sex workers to maintain the same protections as common carriers that mainstream platforms currently enjoy. Moreover, providing legal recognition and protection to both sex workers and the platforms they use would generate opportunities for collaboration between police authorities and the sex industry to deter coercive and unsafe practices.

\section{References}

Abel, G. M. (2014) A decade of decriminalization: Sex work 'down under' but not underground. Criminology \& Criminal Justice. [Online] 14 (5), 580-592.

Acemoglu, D. \& Wolitzky, A. (2011) The Economics of Labor Coercion. Econometrica. [Online] 79 (2), 555-600.

Agustín, L. (2002) Challenging Place: Leaving home for sex. Development. [Online] 45 (1), $110-117$.

Agustín, L. (2006) The Disappearing of a Migration Category: Migrants Who Sell Sex.

Journal of Ethnic and Migration Studies. [Online] 32 (1), $29-47$. 
Armstrong, L. (2020) Decriminalisation of sex work in the post-truth era? Strategic storytelling in neo-abolitionist accounts of the New Zealand model. Criminology \& Criminal Justice. [Online] 174889582091889.

Armstrong, L. (2014) Diverse risks, diverse perpetrators: perceptions of risk and experiences of violence amongst street-based sex workers in New Zealand. International Journal for Crime, Justice and Social Democracy. [Online] 3 (3), 40-54.

Armstrong, L. (2019) Stigma, decriminalisation, and violence against street-based sex workers: Changing the narrative. Sexualities. [Online] 22 (7-8), 1288-1308.

Armstrong, L. \& Abel, G. (2020) Sex work and the New Zealand model: decriminalisation and social change. [online]. Available from:

https://www.jstor.org/stable/10.2307/j.ctv1453kvn (Accessed 3 August 2020).

Barkow, R. E. (2019) Prisoners of politics: breaking the cycle of mass incarceration. Cambridge, Massachusetts: The Belknap Press of Harvard University Press.

Barrios, J. et al. (2020) The Cost of Convenience: Ridehailing and Traffic Fatalities. [online]. Available from: http://www.nber.org/papers/w26783.pdf (Accessed 19 July 2020).

Barry, K. (1995) The prostitution of sexuality. The prostitution of sexuality. New York, NY, US: New York University Press.

Baumeister, R. F. \& Vohs, K. D. (2004) Sexual Economics: Sex as Female Resource for Social Exchange in Heterosexual Interactions. Personality and Social Psychology Review. [Online] 8 (4), 339-363.

Bernstein, E. (2012) Carceral politics as gender justice? The "traffic in women" and neoliberal circuits of crime, sex, and rights. Theory and Society. [Online] 41 (3), 233259.

Bettio, F. et al. (2017) Sex Work and Trafficking: Moving beyond Dichotomies. Feminist Economics. [Online] 23 (3), 1-22.

Blunt, D. et al. (2020) Erased: The Impact of FOSTA-SESTA. [online]. Available from: https://hackinghustling.org/erased-the-impact-of-fosta-sesta-2020/ (Accessed 15 August 2020).

Blunt, D. \& Wolf, A. (2020) Erased: The impact of FOSTA-SESTA and the removal of Backpage on sex workers. Anti-Trafficking Review. [Online] (14), 117-121.

Born, E. J. (2019) TOO FAR AND NOT FAR ENOUGH: UNDERSTANDING THE IMPACT OF FOSTA. NEW YORK UNIVERSITY LAW REVIEW. 941623-1653.

Brennan, J. \& Jaworski, P. (2016) Markets without limits: moral virtues and commercial interests. New York; London: Routledge, Taylor \& Francis Group.

Brents, B. G. \& Sanders, T. (2010) Mainstreaming the Sex Industry: Economic Inclusion and Social Ambivalence. Journal of Law and Society. [Online] 37 (1), 40-60. 
Brooks-Gordon, B. et al. (2015) Production, Income, and Expenditure in Commercial Sexual Activity as a measure of GDP in the UK National Accounts. p.26. [online]. Available from: https://eprints.bbk.ac.uk/17962/ (Accessed 8 June 2020).

Cameron, L. et al. (2020) Crimes Against Morality: Unintended Consequences of Criminalizing Sex Work. p.w27846. [online]. Available from:

http://www.nber.org/papers/w27846.pdf (Accessed 11 October 2020).

Chapkis, W. (1997) Live sex acts: women performing erotic labor. New York: Routledge.

Chapkis, W. (2003) Trafficking, Migration, and the Law: Protecting Innocents, Punishing Immigrants. Gender \& Society. [Online] 17 (6), 923-937.

Chapman-Schmidt, B. (2019) 'Sex Trafficking' as Epistemic Violence. Anti-Trafficking Review. [Online] (12), 172-187.

Citron, D. K. \& Wittes, B. (2018) THE PROBLEM ISN'T JUST BACKPAGE: REVISING SECTION 230 IMMUNITY. 2 (2), 21.

Coase, R. H. (1937) The Nature of the Firm. Economica. [Online] 4 (16), 386-405.

Cohen, M. \& Sundararajan, A. (2015) Self-Regulation and Innovation in the Peer-to-Peer Sharing Economy. University of Chicago Law Review Dialogue. 82118-133.

Cohen, P. et al. (2016) Using Big Data to Estimate Consumer Surplus: The Case of Uber. [online]. Available from: http://www.nber.org/papers/w22627.pdf (Accessed 16 July 2020).

Cole, S. (2018) Pimps Are Preying on Sex Workers Pushed Off the Web Because of FOSTASESTA. Vice. 30 April. [online]. Available from:

https://www.vice.com/en/article/bjpqvz/fosta-sesta-sex-work-and-trafficking (Accessed 10 November 2020).

Colosi, R. \& Lister, B. (2019) Kinking it up: An exploration of the role of online social networking site FetLife in the stigma management of kink practices. Papers from the British Criminology Conference. 19. [online]. Available from: https://www.britsoccrim.org/wp-content/uploads/2019/12/Kinking-it-Up-PBCC19.pdf (Accessed 8 June 2020).

Connelly, L. et al. (2018) Violent and Nonviolent Crimes Against Sex Workers: The Influence of the Sex Market on Reporting Practices in the United Kingdom. Journal of Interpersonal Violence. [Online] 088626051878078.

Cope, S. (2017) Government Pressure Shutters Backpage's Adult Services Section. Electronic Frontier Foundation [online]. Available from: https://www.eff.org/deeplinks/2017/01/government-pressure-censors-backpagecom.

Cramer, J. \& Krueger, A. B. (2016) Disruptive Change in the Taxi Business: The Case of Uber. American Economic Review. [Online] 106 (5), 177-182.

Cunningham, S. et al. (2019) Craigslist Reduced Violence Against Women. [online]. Available from: https://www.scunning.com/craigslist110.pdf. 
Cunningham, S. \& Kendall, T. D. (2016) 'Examining the Role of Client Reviews and Reputation within Online Prostitution', in Scott Cunningham \& Manisha Shah (eds.) The Oxford Handbook of the Economics of Prostitution. [Online]. Oxford University Press. p. [online]. Available from:

http://oxfordhandbooks.com/view/10.1093/oxfordhb/9780199915248.001.0001/oxfor dhb-9780199915248-e-17 (Accessed 28 February 2019).

Cunningham, S. \& Kendall, T. D. (2011) Prostitution 2.0: The changing face of sex work. Journal of Urban Economics. [Online] 69 (3), 273-287.

Cunningham, S. \& Shah, M. (2018) Decriminalizing Indoor Prostitution: Implications for Sexual Violence and Public Health. The Review of Economic Studies. [Online] 85 (3), $1683-1715$.

Cusick, L. (2006) Widening the harm reduction agenda: From drug use to sex work. International Journal of Drug Policy. [Online] 17 (1), 3-11.

Davidson, J. O. (2002) The Rights and Wrongs of Prostitution. Hypatia. [Online] 17 (2), 8498.

Dills, A. K. \& Mulholland, S. E. (2018) Ride-Sharing, Fatal Crashes, and Crime. Southern Economic Journal. [Online] 84 (4), 965-991.

Doyer, A. (2020) Who Sells? Testing Amazon.com for Product Defect Liability in Pennsylvania and Beyond. Journal of Law and Policy. 28 (2), 719-761.

Dworkin, A. (1987) Intercourse. Free Press paperbacks. New York: Simon \& Schuster.

Farley, M. (2004) "Bad for the Body, Bad for the Heart": Prostitution Harms Women Even if Legalized or Decriminalized. Violence Against Women. [Online] 10 (10), 1087-1125.

Garg, V. \& Nilizadeh, S. (2013) 'Craigslist Scams and Community Composition: Investigating Online Fraud Victimization', in 2013 IEEE Security and Privacy Workshops. [Online]. May 2013 San Francisco, CA: IEEE. pp. 123-126. [online]. Available from: http://ieeexplore.ieee.org/document/6565240/ (Accessed 4 August 2020).

Goldman, E. (2018) The Complicated Story of Fosta and Section 230. First Amendment Law Review. 17279-293.

Hays, S. P. (1964) The Politics of Reform in Municipal Government in the Progressive Era. The Pacific Northwest Quarterly. 55 (4), 157-169.

Horning, A. \& Marcus, A. M. (2018) Third party sex work and pimps in the age of antitrafficking.

Horswill, A. \& Weitzer, R. (2018) Becoming a Client: The Socialization of Novice Buyers of Sexual Services. Deviant Behavior. [Online] 39 (2), 148-158.

Hubbard, P. et al. (2008) Regulating sex work in the EU: prostitute women and the new spaces of exclusion. Gender, Place \& Culture. [Online] 15 (2), 137-152. 
Jackson, C. A. \& Heineman, J. (2018) Repeal FOSTA and Decriminalize Sex Work. Contexts. [Online] 17 (3), 74-75.

Jakobsson, N. \& Kotsadam, A. (2013) The law and economics of international sex slavery: prostitution laws and trafficking for sexual exploitation. European Journal of Law and Economics. [Online] 35 (1), 87-107.

Jeffreys, S. (2009) The industrial vagina: the political economy of the global sex trade. RIPE series in global political economy. London; New York: Routledge.

Jones, A. (2015) Sex Work in a Digital Era: Sex Work in a Digital Era. Sociology Compass. [Online] 9 (7), 558-570.

Kevles, D. J. (1999) Eugenics and human rights. BMJ. [Online] 319 (7207), 435-438.

Kingston, S. \& Smith, N. (2020) Sex counts: An examination of sexual service advertisements in a UK online directory. The British Journal of Sociology. [Online] $71(2), 328-348$.

Kinnell, H. (2006) 'Murder made easy: the final solution to prostitution?', in Rosie Campbell (ed.) Sex Work Now. 1st edition [Online]. Willan. pp. 141-168. [online]. Available from: https://www.taylorfrancis.com/books/9781843926771 (Accessed 4 September 2020).

Kitzinger, J. (1992) Sexual Violence and Compulsory Heterosexuality. Feminism \& Psychology. [Online] 2 (3), 399-418.

Kosseff, J. (2019) The twenty-six words that created the Internet. Ithaca [New York]: Cornell University Press.

Kurtz, S. P. et al. (2004) Sex Work and "Date" Violence. Violence Against Women. [Online] $10(4), 357-385$.

Langton, R. (2009) 'Speech Acts and Unspeakable Acts', in Sexual Solipsism. Oxford: Oxford University Press. pp. 25-63.

LeBaron, G. \& Phillips, N. (2019) States and the Political Economy of Unfree Labour. New Political Economy. [Online] 24 (1), 1-21.

Lerum, K. \& Brents, B. G. (2016) Sociological Perspectives on Sex Work and Human Trafficking. Sociological Perspectives. [Online] 59 (1), 17-26.

Lister, B. (2018) 'The impact of criminalisation on indoor sex workers in England and Wales and the need for legislative change', in Sharron A. FitzGerald \& Kathryn McGarry (eds.) Realising justice for sex workers: an agenda for change. Global political economies of gender and sexuality. London: Rowman \& Littlefield International. pp. $21-40$.

Lobel, O. (2018) 'Coase and the Platform Economy', in Nestor M. Davidson et al. (eds.) The Cambridge Handbook of the Law of the Sharing Economy. Cambridge Law Handbooks. [Online]. Cambridge: Cambridge University Press. pp. 67-77. [online]. Available from: https://www.cambridge.org/core/books/cambridge-handbook-of-the- 
law-of-the-sharing-economy/coase-and-the-platformeconomy/1B633BF6482DBFE1B5DCBF18E06892F0.

Logan, T. D. (2010) Personal Characteristics, Sexual Behaviors, and Male Sex Work: A Quantitative Approach. American Sociological Review. [Online] 75 (5), 679-704.

Mac, J. \& Smith, M. (2018) Revolting prostitutes: the fight for sex workers' rights.

Magnanti, B. L. (2013) The sex myth: why everything we're told is wrong. London: Phoenix.

Marcus, A. et al. (2016) Pimping and Profitability: Testing the Economics of Trafficking in Street Sex Markets in Atlantic City, New Jersey. Sociological Perspectives. [Online] 59 (1), 46-65.

Marcus, A. et al. (2019) 'Pimps and Madams', in Frances P. Bernat \& Kelly Frailing (eds.) The Encyclopedia of Women and Crime. [Online]. Hoboken, NJ, USA: John Wiley \& Sons, Inc. pp. 1-6. [online]. Available from:

http://doi.wiley.com/10.1002/9781118929803.ewac0396 (Accessed 4 August 2020).

McCormick, R. L. (1981) The Discovery That Business Corrupts Politics: A Reappraisal of the Origins of Progressivism. The American Historical Review. [Online] 86 (2), 247.

McKee, A. et al. (2015) 'Sex and the virtual suburbs: the pornosphere and community standards', in Paul J. Maginn \& Christine Steinmetz (eds.) (Sub)urban sexscapes: geographies and regulation of the sex industry. Oxford: Routledge. pp. 159-174.

McLean, A. (2015) 'You can do it from your sofa': The increasing popularity of the internet as a working site among male sex workers in Melbourne. Journal of Sociology. [Online] 51 (4), 887-902.

McMenzie, L. et al. (2019) Criminological Policy Mobilities and Sex Work: Understanding the Movement of the 'Swedish Model' to Northern Ireland. The British Journal of Criminology. [Online] 59 (5), 1199-1216.

Monto, M. A. \& Milrod, C. (2014) Ordinary or Peculiar Men? Comparing the Customers of Prostitutes With a Nationally Representative Sample of Men. International Journal of Offender Therapy and Comparative Criminology. [Online] 58 (7), 802-820.

Morrison, C. N. et al. (2018) Ridesharing and Motor Vehicle Crashes in 4 US Cities: An Interrupted Time-Series Analysis. American Journal of Epidemiology. [Online] 187 (2), 224-232.

Munger, M. C. (2018) Tomorrow 3.0: transaction costs and the sharing economy. Cambridge studies in economics, choice, and society. New York: Cambridge University Press.

North, D. C. (1990) Institutions, institutional change, and economic performance. The Political economy of institutions and decisions. Cambridge ; New York: Cambridge University Press.

Oranburg, S. \& Palagashvili, L. (2020) Transaction Cost Economics, Labor Law, and the Gig Economy. Journal of Legal Studies. 49. 
Ostrom, V. (2008) The intellectual crisis in American public administration. 3rd ed. Tuscaloosa: University of Alabama Press.

Otravec, J. A. (2014) Craigslist in Crisis: Issues of Censorship and Moral Panic in the Context of Online Communities. International Journal of the Academic Business World. $6(2), 1-11$.

Pateman, C. (1989) The sexual contract. repr. Oxford: Polity Pr.

Paul, C. \& Wilhite, A. (1994) Illegal markets and the social costs of rent-seeking. Public Choice. [Online] 79 (1-2), 105-115.

Penfold, C. et al. (2004) Tackling client violence in female street prostitution: Inter-agency working between outreach agencies and the police. Policing and Society. [Online] 14 (4), 365-379.

Peterson, M. et al. (2019) The New Virtual Crackdown on Sex Workers' Rights: Perspectives from the United States. Anti-Trafficking Review. [Online] (12), 189-193.

Phoenix, J. (ed.) (2009) Regulating sex for sale: prostitution policy reform and the UK. Bristol, UK ; Portland, OR: Policy Press.

Pitcher, J. (2015) Direct sex work in Great Britain: reflecting diversity. Graduate Journal of Social Sciences. 11 (2), 76-100.

Posner, R. A. (1998) Sex and reason. 4. print. Cambridge, Mass: Harvard Univ. Press.

Powell, B. (2014) Out of poverty: sweatshops in the global economy. Cambridge studies in economics, cognition and society. New York: Cambridge University Press.

Q, S. (2018) New Law Forces Sex-Trafficking Victims to Streets, Dark Web. Rolling Stone. 25 May. [online]. Available from:

https://www.rollingstone.com/culture/features/sesta-fosta-forces-sex-traffickingvictims-streets-dark-web-w520720 (Accessed 31 May 2018).

Raymond, J. G. (2013) Not a choice, not a job: exposing the myths about prostitution and the global sex trade. First edition. Washington, D.C: Potomac Books.

Rekart, M. L. (2005) Sex-work harm reduction. The Lancet. [Online] 366 (9503), 2123-2134.

Reynolds, C. (2020) "Craigslist is Nothing More than an Internet Brothel”: Sex Work and Sex Trafficking in U.S. Newspaper Coverage of Craigslist Sex Forums. The Journal of Sex Research. [Online] 1-13.

Rigg, R. (2010) THE NOT-SO-RISKYBUSINESS OF HIGH-END ESCORTS AND THE INTERNET IN THE 21 ST CENTURY. Richmond Journal of Law and Technology. XVII (1), 1-28.

Rochet, J.-C. \& Tirole, J. (2006) Two-sided markets: a progress report. The RAND Journal of Economics. [Online] 37 (3), 645-667.

Rostow, A. (2005) The hottest spot online. The Advocate. 16 August68-70. 
Russo, R. A. (2020) Online sex trafficking hysteria: flawed policies, ignored human rights, and censorshop. Cleveland State Law Review. 68314-345.

Sanders, T. et al. (2017) Internet Sex Work: Beyond the Gaze.

Sanders, T. et al. (2016) On Our Own Terms: The Working Conditions of Internet-Based Sex Workers in the UK. Sociological Research Online. [Online] 21 (4), 133-146.

Sanders, T. et al. (2020) Paying for Sex in a Digital Age: US and UK Perspectives. 1st edition. [Online]. Abingdon, Oxon; New York, NY : Routledge, 2020.: Routledge. [online]. Available from: https://www.taylorfrancis.com/books/9780429845529 (Accessed 15 August 2020).

Sanders, T. et al. (2018) Prostitution: sex work, policy \& politics. 2nd edition. Los Angeles: SAGE.

Sanders, T. \& Campbell, R. (2007) Designing out vulnerability, building in respect: violence, safety and sex work policy. The British Journal of Sociology. [Online] 58 (1), 1-19.

Scoular, J. (2010) What's Law Got To Do With it? How and Why Law Matters in the Regulation of Sex Work. Journal of Law and Society. [Online] 37 (1), 12-39.

Shortland, A. (2019) Kidnap: inside the ransom business. First edition. Oxford: Oxford University Press.

Simowitz, A. D. (2013) HOW CRIMINAL LAW SHAPES INSTITUTIONAL STRUCTURES: A CASE STUDY OF AMERICAN PROSTITUTION. AMERICAN CRIMINAL LAW REVIEW. 50417-453.

Smith, C. \& Attwood, F. (2013) 'Emotional truths and thrilling slide shows', in Tristan Taormino (ed.) The feminist porn book: the politics of producing pleasure. New York, NY: Feminist Press at the City University of New York. pp. 41-55.

Smith, N. et al. (2015) 'Being, thinking and doing "queer" in debates about commercial sex', in Mary Whowell Laing (ed.) Queer sex work. Routledge studies in crime and society. London; New York: Routledge, Taylor \& Francis Group. pp. 1-9.

Steuer, E. (2015) The Rise and Fall of Redbook, the Site that Sex Workers Couldn't Live Without. Wired. 24 February.

Surprenant, C. W. \& Brennan, J. (2020) Injustice for all: how financial incentives corrupted and can fix the US criminal justice system. [online]. Available from: https://www.taylorfrancis.com/books/9780367855444 (Accessed 1 March 2020).

Tadelis, S. (2016) Reputation and Feedback Systems in Online Platform Markets. Annual Review of Economics. [Online] 8 (1), 321-340.

Tichenor, E. (2020) 'I've Never Been So Exploited': The consequences of FOSTA-SESTA in Aotearoa New Zealand. Anti-Trafficking Review. [Online] (14), 99-115. 
Trautman, L. J. (2016) E-COMMERCE, CYBER, AND ELECTRONIC PAYMENT SYSTEM RISKS: LESSONS FROM PAYPAL. UC Davis Business Law Journal. 16261-307.

Tullock, G. \& McKenzie, R. B. (1975) 'Sexual behavior', in The New World of Economics. Homewoood, Illinois: Richard D. Irwin Inc. p.

Vanwesenbeeck, I. (2017) Sex Work Criminalization Is Barking Up the Wrong Tree. Archives of Sexual Behavior. [Online] 46 (6), 1631-1640.

Vuolajärvi, N. (2019) Governing in the Name of Caring - the Nordic Model of Prostitution and its Punitive Consequences for Migrants Who Sell Sex. Sexuality Research and Social Policy. [Online] 16 (2), 151-165.

Wakefield, C. \& Brents, B. G. (2020) The Influence of Legal Brothels on Illegal Sexual Service Purchasing Habits: The U.S. Context. International Journal of Offender Therapy and Comparative Criminology. [Online] 64 (2-3), 249-264.

Weitzer, R. (2015) Researching Prostitution and Sex Trafficking Comparatively. Sexuality Research and Social Policy. [Online] 12 (2), 81-91.

Weitzer, R. (ed.) (2009) Sex for Sale: Prostitution, Pornography, and the Sex Industry. London: Routledge.

Weitzer, R. (2010) The Movement to Criminalize Sex Work in the United States. Journal of Law and Society. [Online] 37 (1), 61-84.

Weitzer, R. (2007) The Social Construction of Sex Trafficking: Ideology and Institutionalization of a Moral Crusade. Politics \& Society. [Online] 35 (3), 447-475.

Whittaker, M. (2012) Sites set combined record for online prostitution-ad revenue. [online]. Available from: https://aimgroup.com/2012/02/24/sites-set-combined-record-foronline-prostitution-ad-revenue/.

Williamson, O. E. (1985) Reflections on the new institutional economics. Zeitschrift für die gesamte Staatswissenschaft/Journal of Institutional and Theoretical Economics. 141 (1), 187-195.

Witt, E. (2018) After the Closure of Backpage, Increasingly Vulnerable Sex Workers Are Demanding Their Rights. The New Yorker. 8 June. [online]. Available from: https://www.newyorker.com/news/dispatch/after-the-closure-of-backpageincreasingly-vulnerable-sex-workers-are-demanding-their-rights.

Zukerman, W. (2011) Could online prostitution crackdown endanger women? New Scientist. [Online] 212 (2840), 24.

Zwolinski, M. (2012) STRUCTURAL EXPLOITATION. Social Philosophy and Policy. [Online] 29 (1), 154-179. 